\author{
Bogumiła KRYSTEK-KUCEWICZ \\ Krzysztof KASZUBA \\ Instytut Rozwoju Miast, Kraków \\ e-mail: bkrystek@irm.krakow.pl, kkaszuba@irm.krakow.pl
}

\title{
POLITYKA MIESZKANIOWA JAKO NARZĘDZIE OGRANICZANIA DEPOPULACJI: WYBRANE INSTRUMENTY STOSOWANE W POLSKICH MIASTACH
}

\begin{abstract}
Abstrakt: Depopulacja to zjawisko coraz silniej widoczne w polskich miastach. Motywacją osób opuszczających na stałe rodzinne miasto jest dążenie do poprawy warunków życia i pracy. Znaczna grupa osób deklaruje jednak, że zrezygnowałaby z wyjazdu, gdyby w mieście odnalazła możliwość zatrudnienia, odpowiednie warunki mieszkaniowe oraz ofertę spędzania czasu wolnego. Władze miasta mogą $\mathrm{w}$ istotnym stopniu realizować te oczekiwania w ramach prowadzonej polityki mieszkaniowej. Celem artykułu jest przedstawienie tych instrumentów miejskiej polityki mieszkaniowej, które są stosowane, aby ograniczyć zjawisko depopulacji. Przedstawiono m.in. najczęściej wykorzystywane instrumenty, jak również nowatorskie rozwiązania, które są próbą indywidualnego podejścia do problemów charakterystycznych dla wybranych miast.

Słowa kluczowe: depopulacja, mobilność mieszkaniowa, migracje, zasób mieszkaniowy.
\end{abstract}

\section{HOUSING POLICY AS A DEPOPULATION REDUCING TOOL: SELECTED INSTRUMENTS USED IN POLISH CITIES}

Abstract: During last few years depopulation became a phenomenon more visible in Polish cities. The motivation of people to leave a family town is to improve living and working conditions. Cities can respond to demographic processes in a significant way by using proper instruments of the housing policy. The purpose of the author was to present these urban housing policy instruments, which are used to reduce the phenomenon of depopulation. The most frequently used ones are presented as well as innovative solutions, which are an attempt to solve specific problems of selected cities.

Keywords: depopulation, housing mobility, migration, housing policy.

\section{DEPOPULACJA, SKALA I RÓŻNORODNOŚĆ ZJAWISKA}

Prawie $49 \%$ osób chcących zmienić miejsce zamieszkania planuje migrację $\mathrm{w}$ ciągu kilku najbliższych lat. Znaczna ich grupa deklaruje jednak, że zrezygnowałaby $\mathrm{z}$ wyjazdu, gdyby $\mathrm{w}$ rodzinnym mieście odnalazła możliwość zatrudnienia, odpowiednie warunki mieszkaniowe oraz ofertę spędzania czasu wolnego (GUS, 2011, s. 60-61). Mobilność ma wpływ na planowanie polityki mieszkaniowej, ponieważ ludzie w XXI w. są gotowi zmienić miejsce zamieszkania nawet kilka razy w życiu, co kiedyś było niespotykane. Przykładowo, w Belgii średni czas zamieszkiwania jednego mieszkania wynosi 10 lat, w sąsiedniej Holandii 7, w Wielkiej Brytanii 7,5, we Francji 7,5, w Niemczech 8,5, w Luksemburgu 9, a w krajach skandynawskich średnio jest to 5 lat (Meeus, De Decker 2015). Według Cresswell (2006) ta „mobilność miesz- kaniowa" wynika $\mathrm{z}$ chęci zmiany miejsca zamieszkania, ponieważ przestaje ono odpowiadać potrzebom wynikającym ze zmieniającego się etapu lub stylu życia (powiększenie rodziny, starość). Może ona również mieć źródło w braku spójności społecznej obszarów śródmiejskich, często zdegradowanych. Według A. Parkes, A. Kearns (2003) za: Ross (2003) występuje silna korelacja pomiędzy mobilnością a spójnością społeczną w obszarach zabudowy podmiejskiej, gdzie stabilność mieszkaniowa utrzymuje się. Natomiast w śródmiejskich, zdegradowanych dzielnicach, gdzie widoczne jest zubożenie lokalnej ludności, dekapitalizacja zasobu mieszkaniowego i jego niski standard, ludność częściej decyduje się na migrację $\mathrm{w}$ poszukiwaniu lepszego miejsca do zamieszkania. Podobne wnioski przyniosły badania amerykańskich miast i obszarów wiejskich. 
Wykazano w nich, że uboższe osoby i gospodarstwa domowe wykazują znaczną mobilność mieszkaniową (Lawson Clark 2012, za: Cohen i Wardrip).

Depopulacja stanowi ubytek liczby ludności w mieście i/lub regionie, bez znaczenia, czy przyczyną jej występowania jest ruch naturalny czy migracje (Szukalski 2015, Haase 2013). Starsze i bardziej tradycyjne podejście odnosi się do depopulacji powiązanej z pogarszającą się sytuacją ekonomiczną miast, a nowsze jest wieloaspektowym ujęciem tego procesu. Jest on związany ze społeczną, przestrzenną i ekonomiczną restrukturyzacją ośrodków miejskich, której towarzyszy stały ubytek liczby ludności (Stryjakiewicz, red. 2014, za: Zborowski).

Depopulacja nie jest nowym zjawiskiem, występowała już wcześniej. Fazy regresu towarzyszą ewolucji miast, prowadząc do ich degradacji, a w niektórych przypadkach do całkowitego zaniku struktur osadniczych (np. Pompeje, Troja, Machu Picchu). Zmieniły się jednak przyczyny oraz przebieg tego procesu. Wcześniejsze przemiany miast i ich liczby ludności następowały gwałtownie, pod wpływem oddziaływania czynników losowych, takich jak kataklizmy, epidemie czy klęski żywiołowe. Współcześnie proces ten jest dużo silniej uwarunkowany społeczno-ekonomicznym rozwojem miasta (Haase 2013, s. 31-33). Przyjmuje się, że depopulację wywołuje upadek dotychczasowej bazy ekonomicznej (np. Detroit, Pittsburgh), choć nie zawsze jest to czynnik zasadniczy. Na depopulację mają wpływ zachodzące zmiany demograficzne, w tym ubytek naturalny i migracje (mobilność), które są głównym czynnikiem prowadzącym do spadku liczby ludności w miastach (2014). Migracje następują nie tylko w kierunku obszarów podmiejskich (wspierając tym samym rozwój suburbanizacji), lecz także kierują się do innych miast, regionów lub państw.

Problem ubytku liczby ludności doświadcza prawie $42 \%$ miast europejskich liczących ponad 200 tys. mieszkańców. W przypadku Polski spadek liczby ludności miast jest powolny. Oznacza to mniejsze problemy związane z postępującą depopulacją. Gdy średnioroczne tempo spadku przekroczy $1 \%$, wtedy można mówić o kurczących się miastach - (shrinking cities).
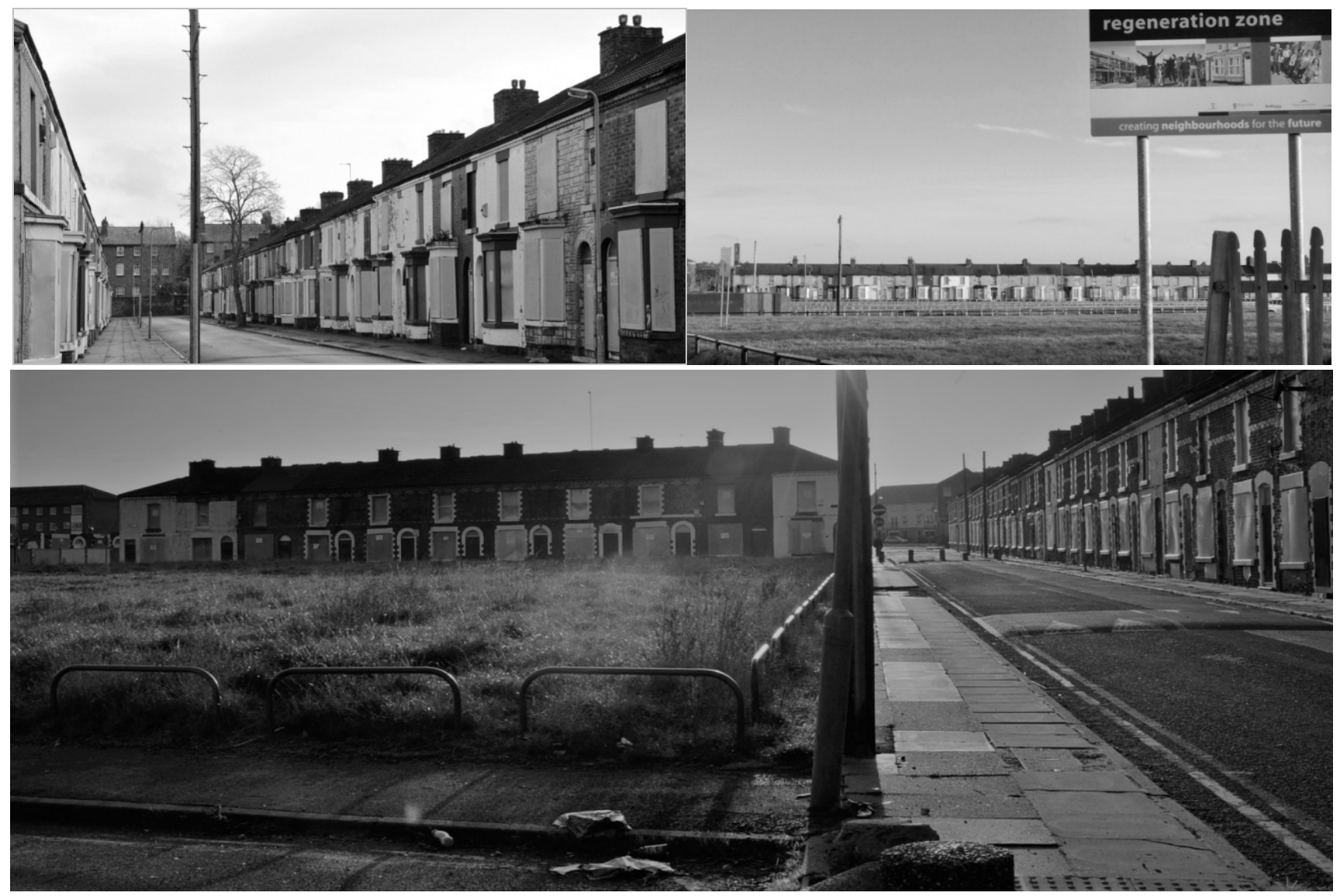

Fot. 1. Liverpool - zdjęcia opuszczonego zasobu mieszkaniowego na trzech obszarach miasta: A - Edge lane, B - Toxteth, C - Everton, oczekujących na nowe zagospodarowanie

(fot. B. Krystek-Kucewicz, 2011) 
Niektóre miasta europejskie zmagają się z depopulacją już od lat 30. XX w. Liverpool w latach 1931-2008 stracił połowę swoich mieszkańców, a w Lipsku ubyło ich 100 tyś. w ciągu zaledwie 10 lat (1989-1998) A. Haase 2013, s. 34, za: Rink i in. 2012). Tak duży ubytek liczby ludności był efektem masowych migracji i złej polityki mieszkaniowej (Olbrycht 2013, s. 23).

Duże dopłaty do nowego budownictwa wywołały opuszczanie "starych zasobów” miast oraz osiedlanie się w strefie podmiejskiej. W odpowiedzi na depopulację miast $\mathrm{w}$ Niemczech Wschodnich zredukowano nadmiar mieszkań wyburzając pustostany, w Liverpoolu zaś opuszczone budynki zostały wyłączone z użytkowania przez gminę i są to obecnie osiedla pustostanów mieszkaniowych i usługowych, które od lat oczekują na nową formę zabudowy mieszkaniowej - o wyższym standardzie i mniejszym zagęszczeniu, zbliżonym do strefy podmiejskiej (fot. 1). W Liverpoolu $80 \%$ nowej zabudowy powstaje bowiem na terenach wcześniej już zagospodarowanych.

Włodarze miasta znaleźli wiele różnych sposobów radzenia sobie $\mathrm{z}$ wyzwaniami depopulacji. W europejskich miastach, problem tzw. zaniku miasta jest rozwiązywany na poziomie regionów metropolitalnych, ponieważ zjawisko depopulacji oddziałuje na strefę podmiejską, a nawet region. Na poziomie regionalnym wprowadzane są różne działania - od opracowywania bilansów ludnościowych, analizy i stymulowania mobilności mieszkaniowej, poprzez realną rewitalizację śródmieść i przestrzeni publicznych. Podjęcie tak różnorodnych działań uruchomiło proces powrotu mieszkańców do miast (Parysek 2013, s. 195).

Również władze polskich miast zaczęły realizować różne działania. Jednym $\mathrm{z}$ nich jest np. bon opiekuńczy dla rodzin $\mathrm{w}$ formie usług i świadczeń społecznych zachęcających do pozostania w województwie opolskim (Depopulacja 2014). Na przykład władze Stalowej Woli w odpowiedzi na depopulację planują wprowadzać instrumenty wspierające rozwój lokalnej gospodarki i nowych miejsc pracy, a także uruchomić programy dla młodych rodzin i inwestować w żłobki, przedszkola i mieszkania komunalne (http://www.pol skieradio.pl).

Celem autorów artykułu było przedstawienie instrumentów polityki mieszkaniowej stosowanych do ograniczenia zjawiska depopulacji w polskich miastach. Wskazane zostały instrumenty oraz ich typologia. Tak skonstruowany cel wymaga odpowiedzi na wiele pytań pomocniczych, w tym: „Czy i jak władze polskich miast postrzegają zjawisko depopulacji? Czy celem po- lityki mieszkaniowej jest odpowiedź na to zjawisko, a jeśli tak, to w jakim kierunku należy podążać - dostosować się do depopulacji czy walczyć z nią? Jakie instrumenty polityki mieszkaniowej zostały wdrożone oraz jakie po ich realizacji oczekiwane są efekty?".

\section{METODY BADAWCZE I OBSZARY BADAŃ}

Aby móc odpowiedzieć na postawione pytania wybrano metodę badania opartą na analizie przypadków. Studium przypadku umożliwia realizację celu artykułu oraz opracowanie zestawień i porównań, a także przedstawienie wyników w odniesieniu do miast różnego rodzaju. Analizę przeprowadzono na grupie miast, które tworzą swoiste kontinuum; jego krańce wyznaczają dwa miasta, w których chce się mieszkać (dodatnie saldo migracji), środek - miasto którego mieszkańcy deklarują chęć pozostania, a koniec cztery miasta, które mieszkańcy chcą opuścić (ujemne saldo migracji).

Grupa siedmiu miast objętych analizą została wyselekcjonowana w wyniku przyjęcia właśnie wymienionych kryteriów: podziału na miasta tracące mieszkańców, stabilne demograficznie i zyskujące mieszkańców. Jednak, jako uzupełnienie etapu rozwoju miasta odzwierciedlonego na osi wspomnianego kontinuum, wprowadzono dodatkowe cechy wytypowanych siedmiu miast, które mogą mieć znaczenie przy analizie celów polityki mieszkaniowej oraz zaproponowanych instrumentów. Wytypowane do badania miasta mają różną liczbę ludności (małe, średnie i duże, zgodnie z klasyfikacją GUS) oraz pozycję w strukturze przestrzennej regionu, tj. są to samodzielne jednostki osadnicze, części obszaru metropolitalnego lub części aglomeracji miejskiej.

Studium przypadku obejmuje miasta, w którym mieszkańcy:

- nie chcą mieszkać, więc migrują w kierunku innych miast, przedmieść lub innych regionów: Rybnik, Poznań, Bytom i Sopot;

- planują nadal mieszkać w tym mieście, pomimo że sąsiaduje ono $\mathrm{z}$ innymi i jest częścią aglomeracji miejskiej: Ruda Śląska;

- planują osiedlać się w nich: Gogolin, Ropczyce.

$\mathrm{W}$ badaniach tych pominięto ośrodek, w którym występuje stałe dodatnie saldo migracji, czyli Warszawę, ponieważ jest to miasto, które należałoby porównywać i zestawiać z podobnymi miastami metro- 
politalnymi - stolicami państw. W nowej polityce mieszkaniowej opracowanej dla Warszawy do roku 2030, wprowadzono informację: „chcemy być pierwszym wyborem dla osób, które decydują się opuścić rodzinne miasta w Polsce, oraz atrakcyjnym miejscem do życia i pracy w Europie". Dlatego analiza wymagałaby uwzględnienia czynników przyciągających ludność do tego miasta, w tym zwłaszcza atrakcyjności stolicy Polski jako miejsca lokalizacji firm i usług o randze międzynarodowej, co znajduje się poza zakresem badań instrumentów polityki mieszkaniowej.

Materiałem badawczym były dokumenty polityki mieszkaniowej przyjmowane $\mathrm{w}$ drodze uchwał przez organy stanowiące (rady miast). Wszystkie miasta - przypadki (poza Gogolinem) - posiadają dokumenty dotyczące polityki mieszkaniowej, w których zdiagnozowano zachodzące procesy demograficzne. Mają one różny horyzont czasowy; najczęściej do lat 2022-2023, choć w jednym mieście określona polityka mieszkaniowa będzie realizowana do roku 2030. W większości tych miast ich polityka mieszkaniowa ma już obowiązujące akty, a kilka dokumentów stanowi projekty przygotowane do uchwalenia.

\section{WYNIKI BADANIA}

\subsection{W JAKI SPOSÓB ZJAWISKO DEPOPULACJI JEST ODZWIERCIEDLONE W POLITYCE MIESZKANIOWEJ? CZY CELEM POLITYKI MIESZKANIOWEJ JEST OGRANICZENIE ZJAWISKA DEPOPULACJI?}

Polityka mieszkaniowa wyznacza kierunek i metody działania stosowane przez gminę do osiągnięcia określonych celów w dziedzinie mieszkalnictwa i zaspokojenia potrzeb mieszkaniowych. W Ustawie z 8 marca 1990 roku o samorządzie gminnym oraz Ustawie z 21 czerwca 2001 roku o ochronie praw lokatorów, mieszkaniowym zasobie gminy $i$ zmianie Kodeksu cywilnego zaspokajanie potrzeb mieszkaniowych jest jednym z zadań własnych gminy. Gminy mają zapewniać lokale socjalne i lokale zamienne, a także zaspokajać potrzeby mieszkaniowe gospodarstw domowych o niskich dochodach. Polityka mieszkaniowa jest narzędziem wykorzystywanym przez gminy głównie w dwóch celach - do planowania i tworzenia warunków do nabycia lub najmu mieszkań przez wszystkich obywateli oraz zapewnienia dostępności zasobu mieszkaniowego i utrzymanie odpowiedniej jakości tego zasobu. Opracowanie szczegółowych założeń poli- tyki mieszkaniowej powinno być poprzedzone analizą zasobu mieszkaniowego, w tym zmian potrzeb mieszkaniowych i podaży mieszkań powiązanej z analizą trendów i warunków demograficznych. Stwierdzenie bowiem, czy liczba mieszkańców wzrasta czy też maleje, może determinować całokształt polityki mieszkaniowej. Wyludnianie się miast może być interpretowane jako bariera rozwojowa albo jako szansa na bardziej efektywne zaspokajanie potrzeb lokalnej społeczności.

Na podstawie analizy siedmiu przypadków możemy wyodrębnić grupy miast, w których występuje:

- depopulacja spowodowana ujemnym saldem migracji - przyczyny takiego stanu rzeczy są różne: zazwyczaj migrują ludzie młodzi, którzy nie widzą dla siebie możliwości rozwoju w obecnym miejscu zamieszkania (Rybnik). Inną przyczyną jest suburbanizacja - mieszkańcy przenoszą się do wsi otaczających miasto, choć zwykle ich aktywność życiowa nadal skupia się w dotychczasowym miejscu zamieszkania. Powodem przeprowadzek są również niższe ceny nieruchomości lub lepsza dostępność gruntów w okolicznych miejscowościach (Poznań);

- depopulacja spowodowana ubytkiem naturalnym - wśród mieszkańców nie obserwuje się wyraźnej tendencji do migrowania do innych miejscowości, dlatego na osi kontinuum zostały zakwalifikowane jako te, w których mieszkańcy chcą pozostać (Ruda Śląska);

- depopulacja spowodowana ujemnym saldem migracji oraz ubytkiem naturalnym (Sopot);

- wzrost liczby ludności - miasta tego typu stanowią zdecydowaną mniejszość; ponieważ celem autorów artykułu było przedstawienie zjawiska depopulacji w kontekście polityki mieszkaniowej, miasta z rosnącą liczbą mieszkańców zaliczono do jednej grupy, niezależnie od tego, czy przyczyną takiego stanu rzeczy jest dodatni przyrost naturalny, dodatnie saldo migracji, czy też oba te zjawiska łącznie (Ropczyce oraz Gogolin).

Badane miasta leżą $\mathrm{w}$ regionach, które tracą mieszkańców, dlatego ich analiza i zestawienie informacji może okazać się kluczowe w niniejszym badaniu.

W tab. 1 przedstawiono sposób, w jaki sytuacja demograficzna została zidentyfikowana i opisana w każdym $\mathrm{z}$ analizowanych przypadków. Informacja na ten temat została zestawiona $\mathrm{z}$ celami przyjętymi $\mathrm{w}$ dokumentach, co pozwala dostrzec ewentualny związek między nimi a diagnozą stanu demograficznego. 
Tab. 1. Identyfikacja sytuacji demograficznej oraz celu polityki mieszkaniowej w odniesieniu do zjawiska depopulacji w wybranych do badań miastach

\begin{tabular}{|c|c|c|c|}
\hline $\begin{array}{c}\text { Model } \\
\text { działania }\end{array}$ & Miasto & Zjawisko depopulacji & Cel polityki mieszkaniowej a depopulacja \\
\hline \multirow{7}{*}{$\begin{array}{l}\text { Model } \\
\text { konku- } \\
\text { rencyjny }\end{array}$} & & \multicolumn{2}{|c|}{ Depopulacja spowodowana ujemnym saldem migracji } \\
\hline & Rybnik & $\begin{array}{l}\text { - Depopulacja wywołana ujemnym saldem } \\
\text { migracji. } \\
\text { - } \text { Dodatni przyrost naturalny. } \\
\text { - } \text { Brak analiz kierunków migracji. } \\
\text { - } \text { Migracja ludzi młodych, którzy nie widzą } \\
\text { możliwości rozwoju w Rybniku. }\end{array}$ & $\begin{array}{l}\text { - Stworzenie warunków dla przyrostu nowych zasobów } \\
\text { mieszkaniowych. } \\
\text { - } \text { Miasto przyjazne lokatorom. Racjonalne } \\
\text { gospodarowanie zasobem gminy. } \\
\text { - Zwiększenie liczby pomieszczeń tymczasowych; } \\
\text { - Budowa mieszkań wspomaganych. } \\
\text { - } \text { Zacieśnienie współpracy ze spółdzielniami } \\
\text { mieszkaniowymi. }\end{array}$ \\
\hline & Poznań & $\begin{array}{l}\text { - Depopulacja wywołana ujemnym saldem } \\
\text { migracji do gmin okalających miasto. } \\
\text { - Przyczyną są wysokie ceny mieszkań na } \\
\text { rynku pierwotnym i wtórnym. }\end{array}$ & $\begin{array}{l}\text { - Poprawa dostępności lokali mieszkalnych i socjalnych } \\
\text { dla osób o niższych dochodach. } \\
\text { - Poprawa jakości zamieszkania w lokalach komunalnych. } \\
\text { - Zwiększenie atrakcyjności Poznania jako miejsca } \\
\text { zamieszkania dla osób o średnich i wyższych dochodach. } \\
\text { - Precyzyjna identyfikacja i wsparcie osób borykających } \\
\text { się z trudnościami mieszkaniowymi. }\end{array}$ \\
\hline & & \multicolumn{2}{|c|}{ Depopulacja spowodowana ubytkiem naturalnym oraz ujemnym saldem migracji } \\
\hline & Sopot & $\begin{array}{l}\text { - Wysoki ubytek naturalny oraz wysokie } \\
\text { ujemne saldo migracji. } \\
\text { — Wzrost liczby osób w wieku } \\
\text { poprodukcyjnym. } \\
\text { - Kierunek migracji to Gdańsk i Gdynia oraz } \\
\text { w mniejszym stopniu miejscowości } \\
\text { sąsiadujące z Trójmiastem. } \\
\end{array}$ & $\begin{array}{l}\text { - Spowalnianie spadku liczby mieszkańców miasta. } \\
\text { - Spowolnienie procesów prowadzących do wzrostu } \\
\text { przeciętnego wieku mieszkańców miasta. } \\
\text { - Wpływanie na strukturę społeczności miasta w ujęciu } \\
\text { uwzględniającym podział na tzw. grupy ekonomiczne } \\
\text { ludności. }\end{array}$ \\
\hline & & \multicolumn{2}{|c|}{$\begin{array}{l}\text { Depopulacja spowodowana ubytkiem naturalnym, ujemnym saldem migracji } \\
\text { i czynnikami gospodarczymi }\end{array}$} \\
\hline & Bytom & $\begin{array}{l}\text { - Wysoki ubytek naturalny. } \\
\text { - Wysokie ujemne saldo migracji przy dużym } \\
\text { udziale migracji zagranicznych. } \\
\text { - Wzrost liczby osób w wieku } \\
\text { poprodukcyjnym. } \\
\text { - } \\
\text { Kierunek migracji na tereny podmiejskie } \\
\text { lub do innych miast. }\end{array}$ & $\begin{array}{l}\text { - Zwiększenie atrakcyjności zamieszkania w mieście } \\
\text { (różnorodny standard). } \\
\text { - Udostępnianie mieszkania na wynajem dla osób } \\
\text { młodych nie zamieszkujących w mieście. } \\
\text { - Urbanistyczna rewitalizacja zaniedbanych dzielnic oraz } \\
\text { przebudowa substancji mieszkaniowej. }\end{array}$ \\
\hline \multirow{4}{*}{$\begin{array}{l}\text { Model } \\
\text { adapta- } \\
\text { cyjny }\end{array}$} & & \multicolumn{2}{|c|}{ Depopulacja spowodowana ubytkiem naturalnym } \\
\hline & $\begin{array}{l}\text { Ruda } \\
\text { śląska }\end{array}$ & $\begin{array}{l}\text { - Ujemny przyrost naturalnym. } \\
\text { - Ujemne saldo migracji. } \\
\text { - Ok. } 80 \% \text { mieszkańców deklaruje chęć } \\
\text { mieszkania w Rudzie Śląskiej, a } 60 \% \\
\text { chciałoby, aby ich dzieci również mieszkały } \\
\text { w tym mieście. }\end{array}$ & $\begin{array}{l}\text { - Kreowanie atrakcyjnych warunków osiedleńczych } \\
\text { i stworzenie konkurencyjnych warunków rozwoju } \\
\text { prywatnych zasobów mieszkaniowych. } \\
\text { - Zintegrowane zarządzanie zasobem mieszkaniowym } \\
\text { z uwzględnieniem wskazań polityki społecznej, zasad } \\
\text { zrównoważonego rozwoju i dziedzictwa kulturowego. }\end{array}$ \\
\hline & & \multicolumn{2}{|c|}{ Rosnąca liczba mieszkańców } \\
\hline & $\begin{array}{l}\text { Rop- } \\
\text { czyce }\end{array}$ & $\begin{array}{l}\text { - Liczba ludności systematycznie wzrasta. } \\
\text { - Dodatni przyrost naturalny, osiągający } \\
\text { wartość 2,8 na } 1000 \text { mieszkańców, sytuuje } \\
\text { gminę w czołówce województwa. } \\
\text { - Wpływ na taki stan ma atrakcyjność } \\
\text { Ropczyc jako miejsca zamieszkania, } \\
\text { możliwość znalezienia pracy oraz przyrost } \\
\text { liczby mieszkań. }\end{array}$ & $\begin{array}{l}\text { - Tworzenie warunków dla realizacji budownictwa } \\
\text { mieszkaniowego bogatszej części ludności Gminy. } \\
\text { - Zapewnienie godziwych warunków mieszkaniowych } \\
\text { osobom o najniższych dochodach. } \\
\text { - Rozwój inicjatyw mieszkaniowych } \\
\text { - }\end{array}$ \\
\hline $\begin{array}{l}\text { Model } \\
\text { mie- } \\
\text { szany }\end{array}$ & Gogolin & $\begin{array}{l}\text { - Liczba ludności systematycznie wzrasta. } \\
\text { - Wpływ na taki stan ma atrakcyjność } \\
\text { Gogolina jako miejsca zamieszkania, } \\
\text { możliwość znalezienia pracy. }\end{array}$ & $\begin{array}{l}\text { - Przeciwdziałania depopulacji poprzez realizację nowego } \\
\text { budownictwa mieszkaniowego dedykowanego nowym } \\
\text { mieszkańcom oraz stwarzanie godnych warunków życia } \\
\text { i zamieszkania osobom starszym i rodzinom z gminy (cel } \\
\text { sformułowany nie bezpośrednio). }\end{array}$ \\
\hline
\end{tabular}

Źródło: opracowanie własne. 
W niektórych przypadkach cele sformułowane są bardzo ogólnie, a związek z problemem depopulacji może być dostrzeżony dopiero na etapie analizy planowanych instrumentów.

Na podstawie analizy przypadków, w tym interpretacji przyczyn zjawiska i celów, można wskazać trzy modele polityki mieszkaniowej, $\mathrm{tj}$.:

1. Model adaptacyjny: akceptacja nowego stanu i dostosowanie do sytuacji demograficznej - depopulacja jest zjawiskiem neutralnym, jest procesem przemian, który się toczy, ale należy go zatrzymać, dlatego poszukiwani są nowi odbiorcy polityki mieszkaniowej bazującej na istniejących mieszkańcach (wcześniej pomijanych), np.: seniorach, absolwentach. Cel polityki mieszkaniowej w kontekście depopulacji wynika z konieczności dostosowania form i sposobu zamieszkania do oczekiwań dokładnie sprecyzowanych grup, które planują pozostać w mieście. Należy podjąć działania rewitalizacyjne, dostarczyć tym grupom odpowiednie warunki mieszkaniowe oraz udostępnić grunty pod budownictwo jednorodzinne zamożniejszym mieszkańcom (Ruda Śląska, Ropczyce).

2. Model konkurencyjny: walka ze zjawiskiem, które jest negatywne - definiowanie celu polityki mieszkaniowej w kontekście depopulacji odnosi się do odwrócenia kierunku migracji i pozyskania gospodarstw domowych oraz jednostek migrujących z okolicznych miast lub z innych regionów. Prowadzi to do stanu, w którym miasta mogą walczyć o mieszkańców. Zdefiniowany cel służy poprawie struktury społeczności miasta, spowolnieniu spadku liczby ludności i procesów prowadzących do wzrostu przeciętnego wieku mieszkańców poprzez zwiększenie liczby młodych osób zamieszkujących zasoby komunalne, poprawę jakości i atrakcyjności zamieszkania, zwiększenie zasobu mieszkań komunalnych poprzez inwestycje i budowę nowych mieszkań (Sopot, Rybnik, Bytom, Poznań).

3. Model mieszany: podejmowanie wielorakich działań, których celem jest zatrzymanie depopulacji i odwrócenie kierunku migracji. Model zakłada dwa główne cele, tj. zwiększanie atrakcyjności oferty mieszkaniowej dla istniejących specyficznych grup mieszkańców (np. seniorów, rodzin wielodzietnych) oraz pozyskanie nowych mieszkańców poprzez wprowadzenie atrakcyjnej oferty zamieszkania i udostępnienia gruntów dla średnio zamożnych mieszkańców. Tym grupom dedykowane są również dodatkowe usługi (np. tymczasowi pracownicy, kobiety, w tym również ciężarne) (Gogolin).

Ciekawym przypadkiem jest polityka mieszkaniowa Sopotu, która definiuje cele wynikające z problemów depopulacji i ma za zadanie niwelowanie tego procesu (cel: spowolnienie spadku liczby mieszkańców; poprawa struktury społecznej miasta lub spowolnienie procesów prowadzących do wzrostu przeciętnego wieku mieszkańców). W innych przypadkach cele sformułowano dość ogólnie. Są one raczej wynikiem analiz demograficznych i są sformułowane bardziej lub mniej bezpośrednio (cel: tworzenie warunków do rozwoju budownictwa mieszkaniowego, w tym budownictwa na wynajem, lub zwiększenie jakości zasobu mieszkań komunalnych poprzez inwestycje oraz budowę nowych mieszkań). Oczywiście nie są to jedyne cele podejmowane przez miasta $\mathrm{w}$ ich polityce mieszkaniowej. Wyselekcjonowano wyłącznie takie, które wynikają z diagnozy demograficznej lub wyzwań, przed którymi stoi miasto.

\subsection{WYNIKI BADANIA: INSTRUMENTY I WYJĄTKOWE ROZWIAZZANIA MIESZKANIOWE}

Z analizy siedmiu przypadków wynika, że mieszkanie zaczyna odgrywać ważną rolę w planowaniu rozwoju miasta. Jest to dziedzina, w której podejmowane działania mogą w istotny sposób wpływać w przyszłości na stan i budżet miasta oraz na funkcjonowanie usług publicznych. Mieszkanie odgrywa ważną rolę w prywatnym, zawodowym, społecznym i kulturowym życiu człowieka. Istotne jest, by cele i instrumenty polityki mieszkaniowej nie tylko odpowiadały na potrzeby rynku mieszkaniowego, ale też respektowały uwarunkowania ekonomiczne i formułowane na poziomie regionalnym i krajowym (Herbst 2013). Przed laty Kraje Europy Zachodniej postawily na budownictwo mieszkaniowe na wynajem. Teraz również $\mathrm{w}$ polskich miastach podejmuje się realizację tego instrumentu. Jednak według raportu mieszkaniowego z 2015 r. powinien być on skierowany w Polsce do dwóch grup społecznych: osób i rodzin o umiarkowanych dochodach, w tym - przede wszystkim - młodych rodzin i gospodarstw jednoosobowych na początku ich kariery mieszkaniowej, oraz do osób i rodzin o niskich dochodach, które nie mają przesłanek do oczekiwania takiego wzrostu dochodów, by kiedykolwiek mogły zajmować nowe mieszkanie w cenie 
rynkowej. W raporcie tym oceniono, że grupa osób o umiarkowanych dochodach to $60-70 \%$ potencjalnego popytu na mieszkania, obecnie współzamieszkujący z rodziną. Jedynie około 10-15\% potencjalnego popytu mieszkaniowego zgłaszają osoby wystarczająco zamożne, by samodzielnie pozyskać mieszkanie (Salomon, Muzioł-Węcławowicz, red. 2015, s. 62-63). Dlatego realizacja instrumentu dostępnych mieszkań na wynajem o umiarkowanym czynszu powinna stać się podstawowym instrumentem polityki mieszkaniowej.
Takie podejście widoczne jest również $\mathrm{w}$ analizowanych przypadkach, w których instrument ten realizowany jest na dwa sposoby - poprzez budowę nowych mieszkań lub udostępnienie szerszej grupie odbiorców zasobu komunalnego. Nie jest to jedyny instrument zaproponowany w kontekście depopulacji. Inne zostały zestawione w tab. 2.

Tab. 2. Zestawienie instrumentów polityki mieszkaniowej w odpowiedzi na depopulację miast na wybranych przykładach

\begin{tabular}{|c|c|c|}
\hline Miasto & Instrumenty w odpowiedzi na depopulację & Odbiorcy \\
\hline$[1]$ & {$[2]$} & {$[3]$} \\
\hline Sopot & $\begin{array}{l}\text { - } \text { Mieszkanie do remontu (dla osób młodych). } \\
\text { - Zamiana mieszkania w gminie na lokale poza miastem, które znajdują się } \\
\text { w sąsiednich miastach oraz ewentualnie w całym kraju (dedykowane rodzinom). } \\
\text { - } \text { Zamiany lokali skierowanych do rodzin 2+2. } \\
\text { - } \text { Zamiana ukierunkowana terytorialnie w celu pozyskania przez miasto lokali } \\
\text { mieszkaniowych w regionach ulegających depopulacji. } \\
\text { - Poszukiwanie starszych mieszkańców prowadzących jednoosobowe gospodarstwo } \\
\text { domowe i zamieszkujących duże mieszkania w celu zamiany ich na mniejsze } \\
\text { (dla rodzin, osób młodych). } \\
\text { - Wymiana i zamiana mieszkań położonych na parterze i udostępnianie ich seniorom. } \\
\text { - Wymiana mieszkań „z urzędu” poprzez złożenie propozycji zamiany na mniejsze } \\
\text { mieszkanie lub o niższym standardzie w celu uniknięcia zaległości czynszowych } \\
\text { i eksmisji. } \\
\text { - Możliwość zawarcia umowy najmu przez osoby spokrewnione do mieszkania } \\
\text { zamieszkałego przez starszego najemcę wymagającego opieki. } \\
\text { - Promowanie wspólnego zamieszkiwania: } \\
\text { a) studentów i absolwentów, } \\
\text { b) starszych osób. }\end{array}$ & $\begin{array}{l}\text { - } \text { Osoby młode. } \\
\text { - } \text { Rodziny, w tym zwłaszcza wielo- } \\
\text { dzietne oraz } 2+2 \text { zamieszkałe w są- } \\
\text { siednich miastach lub ewentualnie } \\
\text { na terenie innych województw. } \\
\text { - } \\
\text { Seniorzy, również zamieszkali poza } \\
\text { miastem i regionem. }\end{array}$ \\
\hline Bytom & $\begin{array}{l}\text { - Wynajem mieszkań komunalnych (pustostanów) do remontu w strefach miasta, } \\
\text { które ulegają depopulacji. } \\
\text { - Publiczne ogłoszenie list wolnych lokali mieszkalnych do najmu i remontu. } \\
\text { - } \text { System zamian mieszkań. } \\
\text { - Wynajem lokali mieszkalnych i ich nabywanie na własność od różnych podmiotów } \\
\text { dysponujących mieszkaniami, w tym od właścicieli mieszkań na rynku wtórnym } \\
\text { i od spółzielni mieszkaniowych. } \\
\text { - Nabywanie budynków mieszkalnych - wykończonych lub będących w trakcie } \\
\text { realizacji. } \\
\text { - Tworzenie rezerwy dla budownictwa mieszkaniowego. } \\
\text { - Przeznaczenie terenów gminnych pod budownictwo mieszkaniowe realizowane } \\
\text { przez różne podmioty gospodarcze. }\end{array}$ & $\begin{array}{l}\text { - Osoby młode (poniżej } 35 \text { lat) } \\
\text { i rodziny z terytorium miasta } \\
\text { oraz innych miast. } \\
\text { - Mieszkańcy miasta. }\end{array}$ \\
\hline Rybnik & $\begin{array}{l}\text { - Rybnicka jednorazowa inicjatywa mieszkaniowa. Mieszkania skierowane do mło- } \\
\text { dych małżeństw (do } 35 \text { lat) i osób z niepełnosprawnością. } \\
\text { - Budowa mieszkań komunalnych. Udostępnienie mieszkań na wynajem z kontrolo- } \\
\text { wanym czynszem połączone z instrumentem udostępniania budynku komunalnego } \\
\text { za grunt pod budownictwo deweloperskie. } \\
\text { - Modernizacja zasobu komunalnego, podwyższenie jego jakości. } \\
\text { - Zamiana mieszkań na mniejsze (seniorzy) i prowadzenie bazy takich lokali } \\
\text { mieszkaniowych. }\end{array}$ & $\begin{array}{l}\text { - } \text { Osoby z niepełnosprawnością. } \\
\text { - } \text { Młode rodziny i małżeństwa } \\
\text { - } \text { o niskich dochodach (nieposiada- } \\
\text { jące zdolności kredytowej umoż- } \\
\text { liwiającej zakup lub najem miesz- } \\
\text { kania na rynku komercyjnym), } \\
\text { skierowane do mieszkańców } \\
\text { Rybnika. } \\
\text { - Osoby młode niezamieszkałe } \\
\text { w mieście, o średnich do- } \\
\text { chodach. }\end{array}$ \\
\hline
\end{tabular}




\begin{tabular}{|c|c|c|}
\hline [1] & [2] & [3] \\
\hline Poznań & $\begin{array}{l}\text { - Zamiana mieszkań zgodnie z potrzebami i możliwościami mieszkańców } \\
\text { - dynamizowanie migracji mieszkańców w obrębie zasobu mieszkaniowego. } \\
\text { - Przeznaczenie pustostanów do remontu. } \\
\text { - } \\
\text { - } \\
\text { Przeznaczanie lokali o powierzchni powyżej } 80 \mathrm{~m}^{2} \text { do przetargu na najem. } \\
\text { - „Mieszkanie dla absolwenta”, mieszkanie na wynajem dla absolwenta, który nie } \\
\text { ukończył } 36 \text { lat, na okres do } 10 \text { lat. Mieszkanie rotacyjne z zasobu TBS. } \\
\text { - Udostępnianie miejskich działek pod budownictwo jednorodzinne w } \\
\text { konkurencyjnych cenach w stosunku do ofert, które nabywcy mogą znaleźć } \\
\text { w gminach ościennych. Konkurowanie z gminami obszaru metropolitalnego } \\
\text { i niwelowanie migracji oraz rozwój suburbanizacji. } \\
\text { - Przygotowanie nowych pól inwestycyjnych pod budownictwo mieszkaniowe. } \\
\text { - Uruchomienie rządowego programu „Mieszkanie Plus”, w ramach którego m.in. } \\
\text { ma zostać zwiększony dostęp do mieszkań dla osób o dochodach uniemożliwia- } \\
\text { jących nabycie lub wynajęcie mieszkania na zasadach komercyjnych oraz zwięk- } \\
\text { szone zaspokojenie potrzeb mieszkaniowych osób zagrożonych wykluczeniem } \\
\text { społecznym. } \\
\text { - Budowa mieszkań na wynajem z dojściem do własności. } \\
\text { - Uruchomienie Miejskiego Biura Najmu. }\end{array}$ & $\begin{array}{l}\text { - Nie wskazano typów odbiorców, tj. ty- } \\
\text { pów gospodarstw domowych, a osoby } \\
\text { o określonych dochodach w tym } \\
\text { osoby, których dochody są: } \\
\text { a) wystarczające do wynajmowania } \\
\text { mieszkań o czynszu rynkowym i pot- } \\
\text { rzeby mieszkaniowe mogą zaspokoić } \\
\text { poprzez najem w zasobie Poznań- } \\
\text { skiego Towarzystwa Budownictwa } \\
\text { Społecznego Sp. z o.o.; } \\
\text { b) na zbyt wysokim poziomie, aby uzys- } \\
\text { kać prawo do lokalu komunalnego, } \\
\text { a zbyt niskie ażeby nabyć mieszkanie } \\
\text { na wolnym rynku, a jednocześnie } \\
\text { osób, które w perspektywie czasu } \\
\text { chciałyby uzyskać własność danej (wy- } \\
\text { najętej) nieruchomości mieszkaniowej; } \\
\text { c) wystarczajace do zaspokojenia swoich } \\
\text { potrzeb mieszkaniowych na wolnym } \\
\text { rynku, zarówno w formie umów } \\
\text { najmu z rynkowym poziomem } \\
\text { czynszu, jak i w formie nabycia prawa } \\
\text { własności do nieruchomości lokalowej, } \\
\text { gruntowej, zabudowanej domem. }\end{array}$ \\
\hline $\begin{array}{l}\text { Ruda } \\
\text { Śląska }\end{array}$ & $\begin{aligned} & \text { Remont zasobu komunalnego. } \\
\text { - } & \text { Konkursowy najem mieszkań do remontu na podstawie zgłoszeń. } \\
\text { - } & \text { Publiczne ogłoszenie list wolnych lokali mieszkalnych przeznaczonych do } \\
& \text { najmu. } \\
\text { - } & \text { Powstanie Banku Zamian Mieszkań - rejestr osób ubiegających się o zamianę } \\
& \text { mieszkania. } \\
\text { - } & \text { Dostosowanie warunków mieszkaniowych do sytuacji rodzinnej poprzez zamianę } \\
& \text { mieszkań. } \\
\text { - } & \text { Zamianę urzędową lokalu mieszkalnego na tańszy w utrzymaniu. } \\
\text { - } & \text { Skojarzenie dobrowolnej zamiany mieszkania. } \\
\text { - } & \text { Zamiana poprzez dostarczenie przez gminę lokalu wolnego w zamian za dotych- } \\
& \text { czas zajmowany przez najemce (polepszenie standardu zamieszkania). } \\
\text { - } & \text { Adaptacje budynków niemieszkalnych na cele mieszkaniowe. } \\
\text { - } & \text { Przygotowanie terenów pod budownictwo realizowane przez inwestorów indy- } \\
& \text { widualnych i deweloperów wraz z wypracowaniem wzoru oferty inwestycyjnej } \\
& \text { (głównie zlokalizowane w centrum miasta). }\end{aligned}$ & $\begin{array}{l}\text { Nie wskazano głównych odbiorców } \\
\text { instrumentów polityki mieszkaniowej. }\end{array}$ \\
\hline Gogolin & 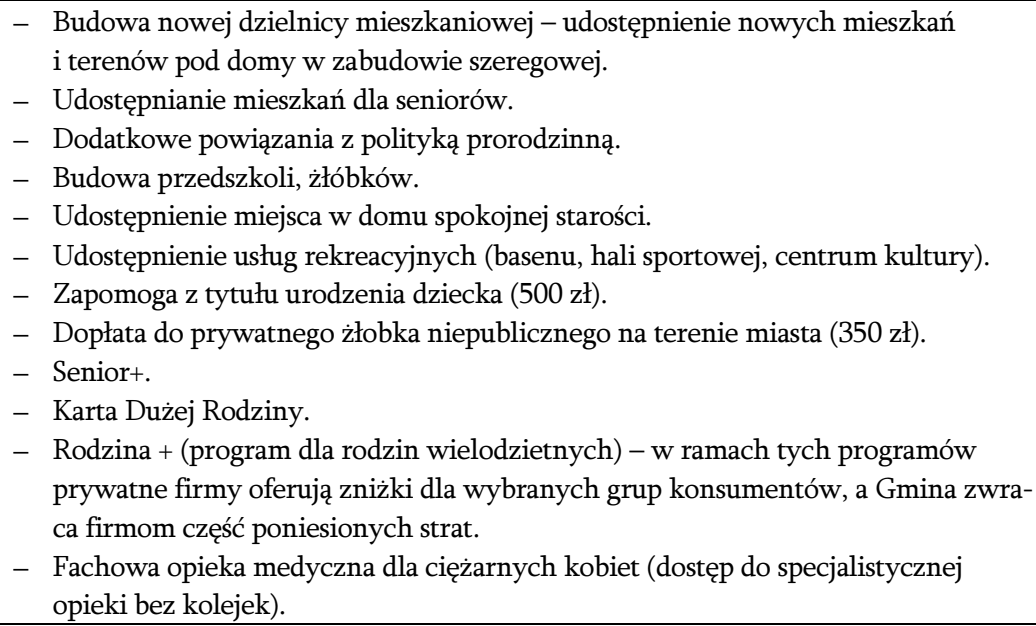 & $\begin{array}{l}\text { - Pracownicy ściągający swoje rodziny } \\
\text { z dziećmi. } \\
\text { - Seniorzy. } \\
\text { - Osoby z niepełnosprawnością. }\end{array}$ \\
\hline Ropczyc & $\begin{array}{l}\text { - Budowa osiedla mieszkaniowego - mieszkania na wynajem oraz własnościowe. } \\
\text { - Udostępnienie terenu pod budownictwo jednorodzinne. }\end{array}$ & $\begin{array}{l}\text { - Rodziny i osoby młode. } \\
\text { - Gospodarstwa domowe o } \\
\text { zróżnicowanym poziomie dochodów. }\end{array}$ \\
\hline
\end{tabular}

Źródło: opracowanie własne. 
Grupę osób, do której kierowana jest polityka mieszkaniowa można podzielić na ludność mobilną i niemobilną. Mobilną grupę stanowią ludzie młodzi, młode rodziny $\mathrm{i}$ gospodarstwa domowe, natomiast grupy nie mobilne to seniorzy oraz osoby $\mathrm{z}$ niepełnosprawnością. $\mathrm{W}$ analizowanych przypadkach polityka mieszkaniowa jest skierowana do obu tych grup, jednak w zależności od konkretnego przypadku nacisk kładziony jest na innych jej odbiorców.

W polityce mieszkaniowej zaproponowano różne instrumenty w celu:

1) pozyskania mieszkańców z innych, sąsiednich miast lub regionów. Są to głównie instrumenty związane z udostępnieniem mieszkania komunalnego potencjalnym mieszkańcom wynajmu (przypadek Rybnika i Bytomia), zamianą mieszkania zlokalizowanego w innym, sąsiednim mieście (przypadek Sopotu) lub budową lokali na wynajem i udostępnieniem terenu pod budownictwo jednorodzinne (przypadek Ropczyc, Gogolina, Poznania);

2) uruchomienia migracji między obszarami miasta oraz zasiedlenie dzielnic notujących spadek liczby ludności. Jest to instrument zamiany lokalu na inny wskazany przez gminę. Umożliwia pozyskanie mieszkań w konkretnej lokalizacji oraz wymianę pomiędzy najemcami zajmującymi zbyt duże lokale w stosunku do swoich potrzeb a najemcami zajmującymi zbyt małe lokale. Oddawane byłyby lokale w takich rejonach, w których potrzeba dbania o liczbę mieszkańców nie jest tak istotna (przypadek Poznania, Sopotu, Rybnika).

3) konkurowania z gminami obszaru metropolitalnego o migrujących w tamtym kierunku mieszkańców wspierających proces suburbanizacji. Wprowadzono instrument udostępniania miejskich działek pod budownictwo jednorodzinne $\mathrm{w}$ konkurencyjnych cenach $\mathrm{w}$ stosunku do ofert, które nabywcy mogą znaleźć w gminach ościennych (przypadek Poznania). Ten instrument jest również powiązany $\mathrm{z}$ rewitalizacją i udostępnianiem terenów zlokalizowanych w centrum miasta (przypadek Rudy Śląskiej).

4) niwelowania przestrzennych oznak depopulacji w mieście, tj. udostępniania pustostanów z przeznaczeniem ich do remontu (przykład Poznania, Rudy Śląskiej i Bytomia).

Warto wymienić tu instrumenty prezentujące wyjątkowe rozwiązania. Wśród nich dominują te z So- potu, gdzie wprowadza się wiele nowatorskich rozwiązań w wyniku przeprowadzenia dogłębnej diagnozy demograficznej i analizy potencjału mieszkaniowego. Opierają się one na systemie zamiany lokali mieszkalnych. Pozostałe analizowane przypadki polityki mieszkaniowej również wprowadzają wyjątkowe rozwiązania. Można wspomnieć o:

1) zamianie na lokale mieszkalne znajdujące się poza miastem - instrument dopuszcza rozszerzenie zamiany mieszkań na zlokalizowane $\mathrm{w}$ miastach sąsiednich oraz ewentualnie na obszar całego kraju. Dopuszczenie takiej zamiany może być uwarunkowane profilem społeczno-ekonomicznym rodziny, która miałaby się zameldować na terenie miasta. W kontekście depopulacji jest ważne, aby pozyskiwać rodziny wielodzietne. Takie rodziny mogą zasiedlać duże lokale, których urząd gminny (dalej: Gmina) nie sprzedała w drodze przetargu;

2) uruchomieniu Miejskiego Biura Najmu - instrument zakłada pomoc osobom mającym trudności w znalezieniu mieszkania na wynajem, poprzez nawiązanie współpracy między Gminą a spółdzielniami mieszkaniowymi, deweloperami i prywatnymi właścicielami. Gmina będzie wynajmowała od tych podmiotów lokale mieszkalne, a następnie podnajmowała je osobom potrzebującym. Głównymi adresatami programu są rodziny z dziećmi (lub samotni rodzice z dziećmi), osoby starsze oraz aktualni najemcy lokali komunalnych. Lokator podnajmujący mieszkanie będzie płacił niższy czynsz, a różnicę między nim a rynkową stawką czynszu pokrywać będzie Gmina;

3) Banku Zamiany Lokali Mieszkaniowych, tj. rejestrze osób ubiegających się o zamianę mieszkania, który można przeglądać celem wyszukania osoby chętnej do zamiany. Zamiana może być dokonana niezależnie od formy własności zasobów mieszkaniowych, ale konieczne jest uzyskanie zgody właściciela nieruchomości podlegającej zamianie. Konieczny jest też tytuł prawny do zajmowanego mieszkania - umowa najmu. W przypadku zamiany lokali pomiędzy najemcą posiadającym umowę na czas oznaczony a najemcą posiadającym umowę na czas nieoznaczony, warunkiem dokonania zamiany jest spełnienie przez obu najemców kryteriów uprawniających do zamieszkiwania $\mathrm{w}$ danej kategorii mieszkań (analogicznie jak w polityce najmu). 
Zamiana może polegać także na dostarczeniu przez Gminę wolnego mieszkania w zamian za dotychczas zajmowane przez najemcę lub osobę zamieszkującą bez tytułu prawnego, jeśli przemawiają za tym szczególne względy społeczne lub interes Gminy;

4) aktywnym poszukiwaniu przez Gminę możliwości zamiany ze starszymi mieszkańcami, którzy prowadzą jednoosobowe gospodarstwo domowe w lokalach o dużym metrażu. Działanie to polegałoby na wyszukiwaniu przez Gminę starszych osób prowadzących jednoosobowe gospodarstwa domowe i proponowaniu im zamiany ich mieszkań na mniejsze $\mathrm{z}$ zasobu mieszkaniowego, a pozyskane duże mieszkania przeznaczane dla rodzin $2+2$ i potencjalnych nowych mieszkańców;

5) realizacji zamiany mieszkań komunalnych - polityka nakierowana na pozyskiwanie rodzin o wielkości co najmniej 2+2, czyli o strukturze najbardziej korzystnej z punktu widzenia wpływu na wzrost liczby ludności w mieście i zmianę struktury grup ekonomicznych (wiek przedprodukcyjny/produkcyjny/poprodukcyjny).

6) powstaniu prywatnego domu seniora jako elementu optymalizacji wykorzystania zasobu komunalnego - najemcy mieszkań komunalnych będą mieli możliwość skorzystania z usług domu seniora, przez co będą częściej decydować się na zwolnienie zajmowanego mieszkania. Prywatny dom seniora byłby alternatywą dla osób, które oczekują wyższego standardu niż w Domu Pomocy Społecznej lub bardziej kameralnej atmosfery;

7) mieszkaniu dla absolwenta, czyli mieszkaniu na wynajem dla absolwenta w wieku poniżej 36 lat na okres do 10 lat - mieszkanie rotacyjne $\mathrm{z}$ zasobu TBS;

8) udostępnieniu prywatnych mieszkań na wynajem z kontrolowanym czynszem - instrument obliguje dewelopera podejmującego się budowy budynku wielorodzinnego do udostępnienia $20 \%$ mieszkań na wynajem z określonym przez Gminę czynszem. Na deweloperze spoczywa obowiązek utrzymania tego zasobu przez okres 10 lat. Pozostałe $80 \%$ mieszkań deweloper może swobodnie sprzedać na wolnym rynku. W ramach instrumentu Gmina może inicjować partnerstwo publiczno-prywatne. Jest to instrument zbliżony do zaproponowanego $\mathrm{w}$ ustawie o rewitalizacji Specjalnej Strefy Rewitalizacji;

9) rybnickiej jednorazowej inicjatywie mieszkaniowej „Mieszkania dla młodych”. Była to pomoc $\mathrm{w}$ dostępie do mieszkań na wynajem skierowana do małżeństw, które nie miały zdolności kredytowej, a uzyskiwane dochody uniemożliwiały im zakup lub najem mieszkania na rynku komercyjnym. Wnioski były oceniane według systemu punktowego, który premiował młode małżeństwa (gdzie młodsze z małżonków nie ukończyło 35 lat), a także osoby niepełnosprawne. Pod uwagę wzięto również powierzchnię mieszkania przypadającą na osobę (im mniejsza powierzchnia, tym więcej punktów) oraz okres zamieszkiwania na terenie Gminy (im dłużej tym więcej punktów). Początkowo program planowano realizować przez dłuższy okres, jednak z uwagi na brak możliwości wynajmowania mieszkań komunalnych na czas oznaczony projekt został zawieszony;

10) wzorze oferty inwestycyjnej dla terenów przeznaczonych do sprzedaży inwestorom prywatnym lub deweloperom. Oferta zawiera opis, tj.: lokalizacja wraz ze współrzędnymi GPS, numery działek, powierzchnia działki, przeznaczenie $\mathrm{w}$ miejscowym planie zagospodarowania przestrzennego, cena wywoławcza, link do ogłoszenia o przetargu, termin przetargu, termin wpłaty wadium, dane kontaktowe, kod $\mathrm{QR}$, mapka sytuacyjna lub zdjęcie lotnicze z zaznaczeniem działek oraz inne istotne dla danej nieruchomości informacje.

Aby polityka mieszkaniowa była skuteczna i efektywna powinna być powiązana z polityką innych sektorów realizowaną w mieście. Jest to istotne zwłaszcza w kontekście potrzeby odpowiedzi na występujący w miastach odpływ ludności i ubytek naturalny. Polityka mieszkaniowa powinna być powiązana z polityką prorodzinną, jak np. w Gogolinie. Miasto zyskuje nowych mieszkańców, ponieważ m.in. daje łatwy dostęp do usług społecznych i rekreacyjno-edukacyjnych, dotowanych dla poszczególnych grup mieszkańców (seniorów, rodzin wielodzietnych czy ciężarnych kobiet). Wprowadzono dotacje dla prywatnego przedszkola i żłobka, co umożliwia aktywizację zawodową kobiet. Miasto szczyci się tym, że zapewnia miejsca pracy, rekreacji, edukacji oraz komfortowe mieszkania i domy dla odbiorców o różnym poziomie dochodów. Zakłada pozyskiwanie mieszkańców również w wieku senio- 
Tab. 3. Typologia instrumentów polityki mieszkaniowej

\begin{tabular}{|c|c|}
\hline Model & stosowane instrumenty w odpowiedzi na depopulację \\
\hline \multirow{5}{*}{$\begin{array}{l}\text { Miasto, } \\
\text { w którym } \\
\text { mieszkańcy } \\
\text { nie chcą } \\
\text { mieszkać }\end{array}$} & $\begin{array}{l}\text { Modernizacja zasobu komunalnego, } \\
\text { - Modernizacja zasobu komunalnego, podwyższenie jego jakości. }\end{array}$ \\
\hline & $\begin{array}{l}\text { Udostępnienie mieszkań na wynajem } \\
\text { - Przeznaczenie pustostanów do remontu i wynajmu, w tym wynajmu pustostanów w strefach miasta, które ulegają depo- } \\
\text { pulacji. } \\
\text { - } \\
\text { - } \text { Przeznaczanie lokali o powierzchni powyżej } 80 \mathrm{~m}^{2} \text { do przetargu na najem. } \\
\text { - } \text { „Mieszkanie dla absolwenta”, mieszkanie na wynajem dla absolwenta, który nie ukończył 36. roku życia na okres nie } \\
\text { dłuższy niż } 10 \text { lat. Mieszkanie rotacyjne z zasobu TBS. } \\
\text { - Uruchomienie rządowego programu „Mieszkanie Plus” oraz budowa mieszkań na wynajem z dojściem do własności. } \\
\text { - } \text { Budowa i udostępnienie mieszkań na wynajem z kontrolowanym czynszem, połączone z instrumentem udostępniania } \\
\text { budynku komunalnego za grunt pod budownictwo deweloperskie. }\end{array}$ \\
\hline & 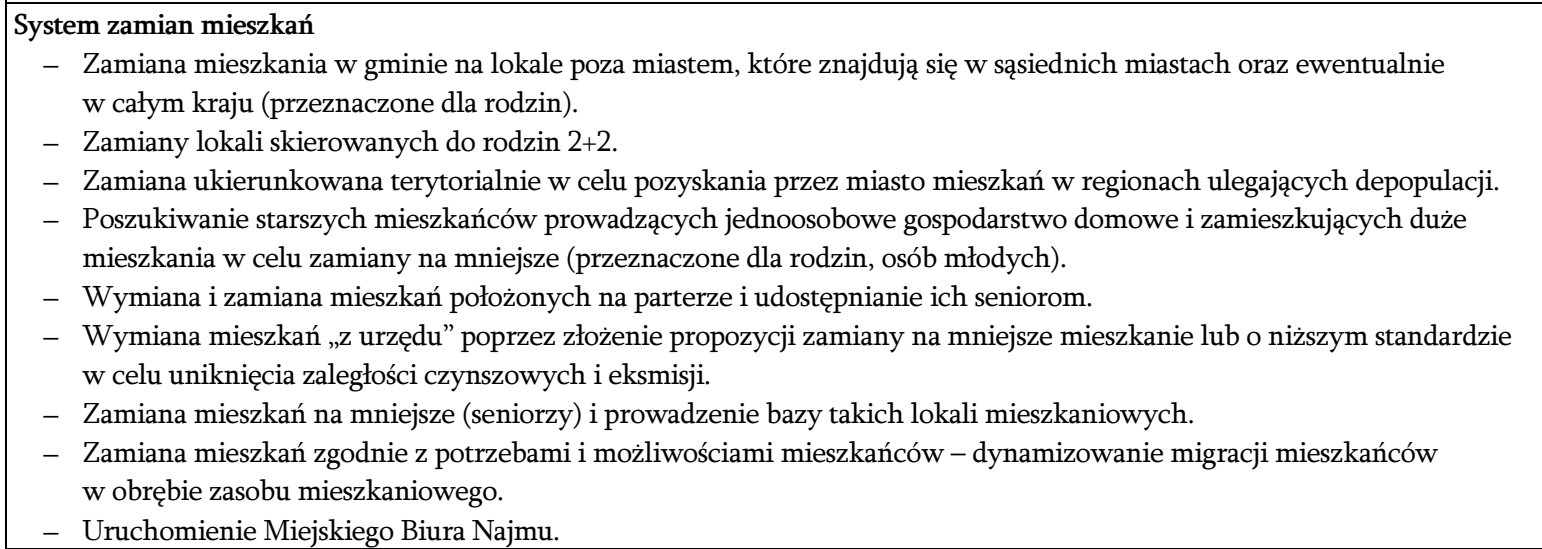 \\
\hline & $\begin{array}{l}\text { Udostępnianie gruntów pod nowe, indywidualne budownictwo mieszkaniowe } \\
\text { - Przygotowanie nowych pól inwestycyjnych pod budownictwo mieszkaniowe. } \\
\text { - Udostępnianie miejskich działek pod budownictwo jednorodzinne w konkurencyjnych cenach w stosunku do ofert, } \\
\text { które nabywcy mogą znaleźć w gminach ościennych. }\end{array}$ \\
\hline & $\begin{array}{l}\text { Wsparcie alternatywnych sposobów zamieszkania } \\
\text { - Promowanie wspólnego zamieszkiwania studentów i absolwentów oraz starszych osób. } \\
\text { - Możliwość zawarcia umowy najmu lokalu zamieszkałego przez starszego najemcę wymagającego opieki z osobami } \\
\text { spokrewnionymi. }\end{array}$ \\
\hline \begin{tabular}{|l} 
Miasto, \\
w którym \\
mieszkańcy \\
planują nadal \\
zamieszkiwać
\end{tabular} & $\begin{array}{l}\text { System zamian mieszkań } \\
\text { - Powstanie Banku Zamian mieszkań - rejestr osób ubiegających się o zamianę mieszkania. } \\
\text { Dostosowanie warunków mieszkaniowych do sytuacji rodzinnej poprzez zamianę mieszkań } \\
\text { - Zamianę urzędową lokalu mieszkalnego na tańszy w utrzymaniu. } \\
\text { - Skojarzenie dobrowolnej zamiany mieszkania. } \\
\text { - Zamiana poprzez dostarczenie przez Gminę lokalu wolnego w zamian za dotychczas zajmowany przez najemcę } \\
\quad \text { (polepszenie standardu zamieszkania). } \\
\text { Udostępnienie mieszkań na wynajem } \\
\text { - } \text { Konkursowy najem mieszkań do remontu na podstawie zgłoszeń. } \\
\text { - Publiczne ogłoszenie list wolnych lokali mieszkalnych przeznaczonych do najmu. } \\
\text { - } \text { Adaptacje budynków niemieszkalnych na cele mieszkaniowe. } \\
\text { Udostępnianie gruntów pod nowe, indywidualne budownictwo mieszkaniowe } \\
\text { - Przygotowanie terenów pod budownictwo realizowane przez inwestorów indywidualnych i deweloperów wraz } \\
\quad \text { z wypracowaniem wzoru oferty inwestycyjnej (głównie zlokalizowane w centrum miasta). }\end{array}$ \\
\hline $\begin{array}{l}\text { Miasto, } \\
\text { w którym } \\
\text { mieszkańcy } \\
\text { planują się } \\
\text { osiedlić }\end{array}$ & $\begin{array}{l}\text { Udostępnianie gruntów pod nowe, indywidualne budownictwo mieszkaniowe } \\
\text { - Budowa nowej dzielnicy mieszkaniowej - udostępnienie nowych mieszkań i terenów pod domy w zabudowie szeregowej } \\
\text { - Udostępnienie terenu pod budownictwo jednorodzinne. } \\
\text { Mieszkania na wynajem } \\
\text { - Budowa osiedla mieszkaniowego z mieszkaniami na wynajem. } \\
\text { Alternatywne sposoby zamieszkania } \\
\text { - Udostępnianie mieszkań dla seniorów. } \\
\text { Dodatkowe powiązania instrumentów z polityką prorodzinną }\end{array}$ \\
\hline
\end{tabular}

Źródło: opracowanie własne. 
ralnym, poprzez instrument budowy mieszkań i domów dla seniorów. Jest to przykład zintegrowanej polityki mieszkaniowej, który przynosi pozytywne efekty w postaci zwiększenia przyrostu naturalnego i przyciągania nowych mieszkańców - a realizowany jest dzięki wprowadzeniu wielu instrumentów na poziomie lokalnym, w województwie opolskim notującym największy w Polsce ubytek liczby ludności.

$\mathrm{W}$ polityce mieszkaniowej zastosowano wiele instrumentów, które, uszeregowane zgodnie z modelem miasta i jego etapem rozwoju demograficznego, umożliwiają wskazanie ogólnej ich typologii (tab. 3). Najwięcej instrumentów zaplanowano $\mathrm{w}$ polityce mieszkaniowej tych miast, w których mieszkańcy nie chcą mieszkać. Planuje się tam wiele działań hamujących negatywne trendy oraz zwiększających atrakcyjność i konkurencyjność w stosunku do miast sąsiednich lub gmin podmiejskich. Charakterystyczne typy instrumentów zostały uszeregowane według wachlarza możliwych do zastosowania rozwiązań w odpowiedzi na depopulację miast, a nie według liczby miast stosujących dane rozwiązania.

W przypadku miast tracących mieszkańców typologia zaplanowanych instrumentów przedstawia się następująco:

- system zamiany mieszkań - z podziałem na instrumenty odnoszące się do przestrzennej lokalizacji mieszkania, powierzchni, położenia $\mathrm{w}$ budynku, lokatorów i potencjalnych beneficjentów. Celem realizacji tego instrumentu jest umożliwienie najemcom dostosowanie rodzaju mieszkania do swoich możliwości finansowych. Jest to najliczniejsza grupa instrumentów. Należy jednak pamiętać, że większość instrumentów została zaplanowana $\mathrm{w}$ odniesieniu do polityki mieszkaniowej jednego miasta (Sopot). Wprawdzie inne ośrodki przedstawiały również rozwiązania dotyczące zamiany mieszkań, ale nie były one zbyt liczne;

- budowa lub udostępnienie mieszkań na wynajem - z podziałem na instrumenty dotyczące udostępnienia pustostanów do remontu, dużych mieszkań $\mathrm{w}$ ramach przetargu, wynajmowania mieszkań prywatnych czy budowy mieszkań, w tym również z udziałem prywatnych inwestorów;

- udostępnianie gruntów pod nowe indywidualne budownictwo mieszkaniowe $-\mathrm{z}$ podziałem na instrumenty dotyczące przygotowania terenów inwestycyjnych lub miejskich działek pod budownictwo jednorodzinne;
- wsparcie alternatywnych sposobów zamieszkania - odnoszące się do wspólnego zamieszkania różnych osób. Instrumenty nastawione są na łączenie osób znajdujących się w podobnym wieku, np. senior-senior lub student-absolwent, ale także budowanie relacji międzypokoleniowych opartych na wymianie usług, np. senior - opiekun;

- modernizacja zasobu komunalnego.

W miastach, w których mieszkańcy planują nadal mieszkać stosuje się instrumenty powiązane z procesem depopulacji, zbieżne $\mathrm{z}$ podejmowanymi w miastach tracących mieszkańców. Są to m.in.: system zamiany mieszkań, udostępnienie mieszkań na wynajem i udostępnienie gruntów pod budownictwo indywidualne. Jednak preferowany jest rozwój budownictwa na obszarach śródmiejskich, lub innych wcześniej zagospodarowanych. Włodarze miast, w których mieszkańcy planują się osiedlić podejmują instrumenty wspierające w znacznej mierze rozwój budownictwa mieszkaniowego oraz udostępnienie gruntów pod zabudowę jednorodzinną. Planuje się tam również realizację instrumentu budowy mieszkań na wynajem oraz udostępnienia mieszkań seniorom. W stosunku do miast, w których mieszkańcy nie chcą mieszkać, występuje odwrócona logika wybieranych instrumentów (tab. 4). W miastach tracących mieszkańców realizuje się zamianę mieszkań, budowę mieszkań na wynajem, a dopiero w dalszej kolejności udostępnianie terenów pod indywidualne budownictwo.

Tab. 4. Typologia instrumentów polityki mieszkaniowej $\mathrm{z}$ podziałem na rodzaje miast

\begin{tabular}{|c|l|l|l|}
\hline \multirow{2}{*}{ Lp. } & \multicolumn{3}{|c|}{ Miasto, w którym mieszkańcy } \\
\cline { 2 - 4 } & nie chcą mieszkać & $\begin{array}{l}\text { planują nadal } \\
\text { mieszkać }\end{array}$ & \multicolumn{1}{c|}{ planują się osiedlić } \\
\hline 1 & $\begin{array}{l}\text { System zamiany } \\
\text { mieszkań }\end{array}$ & $\begin{array}{l}\text { System } \\
\text { zamiany } \\
\text { mieszkań }\end{array}$ & $\begin{array}{l}\text { Udostępnienie gruntów } \\
\text { pod indywidualne } \\
\text { budownictwo, budowa } \\
\text { osiedli mieszkaniowych }\end{array}$ \\
\hline 2 & $\begin{array}{l}\text { Budowa i udostęp- } \\
\text { nienie mieszkania } \\
\text { na wynajem }\end{array}$ & $\begin{array}{l}\text { Udostępnienie } \\
\text { mieszkania na } \\
\text { wynajem }\end{array}$ & $\begin{array}{l}\text { Budowa mieszkania na } \\
\text { wynajem }\end{array}$ \\
\hline 3 & $\begin{array}{l}\text { Udostępnienie } \\
\text { gruntów pod } \\
\text { indywidualne } \\
\text { budownictwo }\end{array}$ & $\begin{array}{l}\text { Udostępnienie } \\
\text { gruntów pod } \\
\text { indywidualne } \\
\text { budownictwo }\end{array}$ & $\begin{array}{l}\text { Alternatywne sposoby } \\
\text { zamieszkania }\end{array}$ \\
\hline 4 & $\begin{array}{l}\text { Alternatywne } \\
\text { sposoby zamiesz- } \\
\text { kania }\end{array}$ & $\begin{array}{l}\text { Remont zasobu } \\
\text { komunalnego }\end{array}$ & - \\
\hline
\end{tabular}

Źródło: opracowanie własne. 


\subsection{WSKAŹNIKI I PLANOWANE EFEKTY}

Opracowaniu założeń polityki mieszkaniowej powinno towarzyszyć przyjęcie odpowiednich wskaźników, które pozwolą w przyszłości ocenić skuteczność podejmowanych działań. Wskaźniki nie tylko powinny być przypisane do konkretnych instrumentów, lecz również należy je wiązać z celami polityki mieszkaniowej, aby na etapie monitoringu i ewaluacji można było określić stopień realizacji programu i osiągnięcia planowanych efektów oraz (ewentualnie) wprowadzić doń zmiany. Wypracowanie wskaźników powinno być istotnym elementem każdego dokumentu z zakresu polityki mieszkaniowej. Analiza przypadków prowadzi do wniosku, że obecnie jest to jedna $\mathrm{z}$ zaniedbanych części miejskiej polityki mieszkaniowej. W niektórych tylko dokumentach określono wskaźniki dotyczące wybranych instrumentów, np.:

- udostępnienie 162 działek pod budownictwo jednorodzinne (Ropczyce),

- budowa 30-50 nowych mieszkań w latach 2017 -2023 (Rybnik),

- przygotowanie nowych pól inwestycyjnych z przeznaczeniem na budownictwo mieszkaniowe, $\mathrm{z}$ docelową liczbą 3000 lokali mieszkalnych (Poznań).

$\mathrm{W}$ żadnym zaś $\mathrm{z}$ analizowanych dokumentów nie ma refleksji, jak planowane działania mogą całościowo zmienić sytuację demograficzną w mieście. Taką ocenę utrudnić mógł fakt, że nie wszystkim z zakładanych instrumentów przypisano wskaźniki. W niektórych dokumentach nie ma ich dla żadnego z instrumentów (Ruda Śląska, Sopot). Oznacza to, że niektóre instrumenty w praktyce mogą być najwyżej traktowane jako zalecenia lub mogą prowadzić do podejmowania działań pozornych.

Niekiedy (na podstawie dotychczasowych doświadczeń) określano prognozy odnośnie do wybranych zjawisk, np. stanu ludności miasta i potrzeb mieszkaniowych na koniec obowiązywania programu (Ruda Śląska), albo wielkości i stanu miejskiego zasobu mieszkaniowego na każdy rok obowiązywania programu (Sopot). Nie określono jednak przy tym, jak duży wpływ będą miały proponowane instrumenty polityki mieszkaniowej na zmianę tych wartości. Wydaje się, że temat wskaźników, monitoringu i ewaluacji w dokumentach z zakresu polityki mieszkaniowej powinien być poważniej potraktowany, szczególnie w miastach, w których stwierdzono występowanie istotnych problemów, np. wysokie ujemne saldo migracji lub wysoki ubytek naturalny.

\section{WNIOSKI KOŃCOWE}

Depopulacja w polityce mieszkaniowej jest określana w różny sposób - jako zjawisko negatywne, z którym należy walczyć, neutralne, które można akceptować poszukując nowych odbiorców polityki mieszkaniowej, lub jako negatywne i neutralne jednocześnie. Odnosząc się do etapu rozwoju miasta wskazanego na osi kontinuum władze miasta, w których mieszkańcy nie chcą już mieszkać postrzegają depopulację negatywnie, natomiast, w których chcą pozostać lub planują się osiedlić, odnoszą się do tego zjawiska w sposób neutralny lub mieszany. W większości przypadków depopulacja jest jednak oceniana negatywnie. Włodarze polskich miast nie widzą w depopulacji takich pozytywnych aspektów, jak np. możliwość lepszego zaspokojenia potrzeb zmniejszonej lokalnej społeczności, sprawniejszego zarządzania miastem, zmiany podejścia w sferze mieszkaniowej z „ilościowego” na ,jakościowe".

Dokumenty z zakresu polityki mieszkaniowej nie mają kompleksowego charakteru, który umożliwiłby rozwiązanie problemu depopulacji. Nie są też powiązane z polityką innych sektorów miasta. Nawet gdy zjawisko depopulacji zostało $\mathrm{w}$ dokumencie dostrzeżone i określone jako istotne, nie przeprowadza się w nim pogłębionej analizy skutków proponowanych instrumentów polityki. Tylko w jednym przypadku założono jako cel zmianę struktury społeczno-demograficznej ( $\mathrm{w}$ wyniku realizacji wielu instrumentów polityki mieszkaniowej) - jednak nie zaproponowano wskaźników umożliwiających monitowanie efektów realizacji tego celu.

Włodarze miast, z których mieszkańcy chcą wyjechać zakładają chęć pozyskania dużej liczby „nowej” ludności, co umożliwi im poprawne funkcjonowanie. Nastawione są one na konkurowanie o mieszkańca. Takie podejście może wydawać się uzasadnione, ponieważ są to duże i średnie miasta, w których nastąpił znaczny odpływ ludności do sąsiednich miast lub wsi. Polityka mieszkaniowa prezentuje w ich przypadku:

1) zwiększenie atrakcyjności mieszkaniowej poprzez:

- tworzenie warunków do rozwoju budownictwa mieszkaniowego (w tym budownictwa na wynajem),

- podwyższenie jakości zamieszkania (w tym zasobu mieszkań komunalnych) poprzez inwestycje;

2) spowolnienie spadku liczby ludności; 
3) spowolnienie procesów, które prowadzą do wzrostu przeciętnego wieku mieszkańców miasta;

4) poprawę struktury wieku ludności miasta w podziale na trzy grupy ekonomiczne ludności (przed-i poprodukcyjnym oraz produkcyjnym).

Są to cele odnoszące się do poprawy sfery przestrzenno-demograficznej miasta. Dominuje więc pogląd, że zwiększenie atrakcyjności miasta umożliwi zahamowanie zachodzącego $\mathrm{w}$ nim procesu depopulacji. Jednak z literatury przedmiotu wynika, że problem depopulacji jest dużo bardziej złożony i wymaga zastosowania wielosektorowych instrumentów.

Władze miasta, w którym mieszkańcy planują nadal zamieszkiwać wskazały dość ogólny cel przeciwdziałania depopulacji, poprzez rewitalizację zwiększającą atrakcyjność zasobu mieszkaniowego (budowa i rewaloryzacja), a w miastach, w których mieszkańcy planują się osiedlić proponują:

- rewitalizację;

- tworzenie warunków do rozwoju budownictwa mieszkaniowego i rozwoju inicjatyw mieszkaniowych;

- budowę mieszkań;

- zapewnienie dobrych warunków mieszkaniowych osobom o najniższych dochodach.

Wszystkie cele realizowane przez włodarzy różnych typów miast odnoszą się do podwyższania ich atrakcyjności mieszkaniowej, jednak przy zastosowaniu różnych instrumentów. Pojawiły się rozwiązania wręcz nowatorskie, $\mathrm{w}$ tym system zamiany mieszkań poza obszarem miasta. Zaplanowano również wykorzystanie pustostanów, oddanie ich potencjalnym mieszkańcom z miasta i spoza jego granic do wynajmu i remontu. Adaptacja pustostanów na cele mieszkaniowe lub podnoszenie ich standardu mogą zwiększyć atrakcyjność miasta w oczach osób rozważających powrót do niego. Takie lokale można szybko dostosować do nowych potrzeb, ponieważ posiadają odpowiednią infrastrukturę techniczną - przyłącza mediów (wodno-kanalizacyjne, c.o., gaz) oraz dostęp do infrastruktury drogowej i społecznej.

W miastach, w których mieszkańcy nie chcą już mieszkać zaplanowano zastosowanie największej liczby instrumentów. Wśród nich najważniejszymi są: system zamiany mieszkań, budowa mieszkań na wynajem, udostępnianie gruntów pod budownictwo jednorodzinne, realizacja alternatywnych form zamieszkania oraz remont istniejącego zasobu komunalnego. To właśnie przed taką polityką mieszkaniową stoi ważne zadanie, ponieważ tworzy ona bogate instrumentarium wymagające koordynacji i sprawnego zarządzania.

W mieście, w którym mieszkańcy planują nadal mieszkać zastosowano system zamian mieszkań, udostępniono mieszkania na wynajem oraz tereny pod indywidualne budownictwo - na obszarach centralnych miasta lub na terenach wcześniej już zagospodarowanych. Niniejsza analiza nie pozwala na wyciągniecie większej liczby wniosków, ponieważ studium przypadku dotyczyło jednego takiego miasta, co do którego mamy dowody w postaci ankiet opinii publicznej o chęci pozostania w tym mieście.

Natomiast władze miast, których mieszkańcy planują zasiedlić się realizują instrumenty skierowane do różnych odbiorców - od udostępnienia gruntów pod indywidualne budownictwo, budowę osiedli mieszkaniowych i mieszkań na wynajem, aż po alternatywne sposoby zamieszkania. Najczęściej programy te są skierowane do rodzin oraz osób młodych.

W żadnym z przypadków nie było odniesienia do feminizacji mobilności, czyli kobiet jako grupy najbardziej mobilnej oraz do wyników amerykańskich badań, według których największą mobilność wykazują ludzie mniej majętni/ubodzy. Prawdopodobnie to właśnie do nich powinny być kierowane instrumenty miast nastawionych na przyciąganie nowych mieszkańców. Tylko w Gogolinie nieliczne instrumenty polityki prorodzinnej są skierowane do kobiet. Są to instrumenty, które mają zadbać o zdrowie kobiet ciężarnych poprzez dostęp do usług medycznych oraz umożliwić kobietom powrót do pracy, udostępniając przedszkola i żłobki oraz dopłacając do prywatnej opieki przedszkolnej. Nie są to instrumenty mieszkaniowe skierowane tylko do kobiet, ale warto zaznaczyć fakt, że ich potrzeby zostały tu zauważone i powiązane pośrednio z polityką mieszkaniową.

Przeprowadzone badania przynoszą również inne wnioski. Włodarze miast prowadzą politykę mieszkaniową nastawioną na ograniczenie zjawiska depopulacji poprzez wprowadzenie różnorodnych instrumentów, nie monitorują jednak efektów tych działań. Nie określają też wskaźników pomocnych przy monitorowaniu słuszności danej polityki mieszkaniowej. Nie będzie więc można sprawdzić, czy realizacja poszczególnych instrumentów przyniosła oczekiwane efekty, tj. czy zwiększono dodatnie saldo migracji i ograniczono depopulację. Bez wątpienia monitoring jest najsłabszym elementem polityki mieszkaniowej przedstawionej w tym artykule. 


\section{BIBLIOGRAFIA}

Depopulacja. Czas na zmiany na opolskim rynku pracy. Raport końcowy, 2014, Centrum im. Adama Smitha, Urząd Marszałkowski Województwa Opolskiego, Opole.

Haase A., 2013, No one-size-fits-all. O różnorodności kurczących się miast $w$ Europie, [w:] Zarządzanie rozwojem miast o zmniejszającej się liczbie mieszkańców (w kontekście perspektywy finansowej 2014-2020), Kancelaria Senatu, Warszawa, s. 31-45.

Herbst I., 2013, Problemy mieszkaniowe w Polsce. Dostęp do mieszkania $w$ kontekście polityki prorodzinnej, Warszawa.

Jaroszewska E., Ciesiółka P., 2010, Strategie rewitalizacji $W$ „kurczących się miastach” - doświadczenia europejskie, „Problemy Rozwoju Miast", s. 13-21.

Lawson Clark S., 2012, In search of housing: Urban families in rural contexts, „Rural Sociology”, 77(1), s. 110-134.

Meeus B., De Decker P., 2015, Staying put! A housing pathway analysis of residential stability in Belgium, „Housing Studies”, 30, 7, s. 1116-1134.

Olbrycht J., 2013, Shrinking cities - problem globalny, problem europejski, [w:] Zarządzanie rozwojem miast o zmniejszającej się liczbie mieszkańców (w kontekście perspektywy finansowej 2014-2020), Kancelaria Senatu, Warszawa, s. 31-45.
Parkes A., Kearns A., 2003, Residential perceptions and housing mobility in Scotland: An analysis of the Longitudinal Scottish House Condition Survey 1991-96, „Housing Studies”, 18, 5, s. 673-701.

Salomon M., Muzioł-Węcławowicz A. (red.), 2015, Mieszkalnictwo w Polsce. Analiza wybranych obszarów polityki mieszkaniowej, Habitat for Humanity, Warszawa.

Stryjakiewicz T. (red.), 2014, Kurczenie się miast $w$ Europie Środkowo-Wschodniej, Bogucki Wyd. Naukowe, Poznań.

Szukalski P., 2014, Depopulacja dużych miast w Polsce, „Demografia i Gerontologia Społeczna - Biuletyn Informacyjny”, 7.

Szukalski P., 2015, Depopulacja województwa zachodniopomorskiego - teraźniejszość i przyszłość, opracowanie na zlecenie Zachodniopomorskiego Urzędu Marszałkowskiego.

http://www.polskieradio.pl/42/2443/Artykul/1622817,Depopulacjaczyli-polskie-miasta-sie-wyludniaja-Jak-sobie-radza-z-tym-wiel kim-problemem; 02.06.2017.

Artykuł wpłynął:

11 lipca 2017

Zaakceptowano do druku:

12 października 2017 